\title{
The Influence Of Family Support To Patients'anxiety Of Chronic Renal Failure Withexperience Of Hemodialysis At The Hemodialysis Unit Of Ulin Hospital Banjarmasin
}

\author{
Rina Al Kahfi ${ }^{{ }^{*}}$ \\ ${ }^{1}$ Department of Science Nursing, STIKES Sari Mulia, Banjarmasin Indonesia \\ 'rina_al_kahfi@stikessarimulia.ac.id
}

Subhannur Rahman ${ }^{1}$

${ }^{1}$ Department of Science Nursing, STIKES Sari Mulia, Banjarmasin Indonesia subhannur_rahman@stikessarimulia.ac.id

Adriana Palimbo ${ }^{2}$

${ }^{2}$ Midwifery Academy of Sari Mulia, Banjarmasin Indonesia

Adriana_palimbo@akbidsarimulia.ac.id

\author{
Nina Novita Sari ${ }^{1}$ \\ ${ }^{1}$ Department of Science Nursing, STIKES Sari Mulia, Banjarmasin Indonesia \\ Nina_novitasari@gmail.com
}

\begin{abstract}
Objective: Knowing the influence of family support to patients' anxiety of chronic renal failure with experience of hemodialysis at the hemodialysis unit of UlinHospital Banjarmasin.

Method: The research method was descriptive correlative with cross sectional approach. Data sampling in the study conducted by purposive sampling as many as 75patients. The data collection was done by using questionnaire and analyzed by using Chi Square on the degree of confidence $(0,05) 95 \%$.

Results: Respondents had negative support from the family of 40 people $(53,3 \%)$. Respondents experience of severe anxiety that were $41(54,7 \%)$. There was influence of family support to patients' anxiety of chronic renal failure with experience of hemodialysis at the hemodialysis unit of UlinHospital Banjarmasin( $\mathrm{p}=0,000<\alpha=0,05)$.

Conclusion: Conclusion of this research showed that There was influence of family support to patients' anxiety of chronic renal failure with experience of hemodialysis at the hemodialysis unit of UlinHospital Banjarmasin $(\mathrm{p}=0,000<\alpha=0,05)$.
\end{abstract}

Keywords:, Anxiety,Chronic Renal Failure, Family Support ,Hemodialysis

\section{INTRODUCTION}

Prevalence of kidney failure chronicle based on diagnosis doctor in Indonesia is 0,2\%.North Sulawesi ranked to 4 highest of 33 provinces prevalence of $0,4 \%$ in 2013. Is survey by the bar nephrologyIndonesiaon four towns in Indonesia, by examining the creatinine serum 1200 people, obtained prevalence of kidney disease chronicle large enough that is $12,5 \%$ [1].

The data in 2013 showed that as many as 6,2percents of the population of the Indonesian population suffering from kidney failure. Of a digit $6,2 \%$ it, many patients who had kidney failure chronicle the stage five, is predicted to reach $0,8 \%$ of the total number of 
patients with renal failure in Indonesia which is about 104 thousand people, meanwhile the number of patients with renal failure in Indonesia year 2014 reaches 300 thousand people, where this figure is expected to continue to increase for an extended period of time to come [1].

The case of kidney failure in south Kalimantan the highest in 2012 is the city of Banjarmasin 1497 cases, the second is KabupatenBanjar namely 742 cases and the third was tapin with the number of cases as many as 641 scene [1].

The patient with kidney failure chronicle who choosehemodialysis as therapy a substitute for kidney function will undergo the therapy for his life except patients undergo kidney transplantation.Dependence the patient with kidney failure chronicle to hemodialysis the rest of his life, will affect widely and pose a problem either physically, psikososial, and economic. Complexity problems that have emerged in patients kidney failure chronicle who underwent hemodialysis will result in the anxiety on the patient [2].

Support is an important factor required someone when faced with including healthproblems.Family encouragement in patientshemodialysis needed the rest of his life. A patient with a kidney chronic to undergo hemodialysisneeds family encouragement the rest of his life because most to undergo hemodialysisa lifetime.Hence family encouragement plays an important role important so that the patient re willing to invest in hemodialysis and can receive the state of disease [3].

Patients with renal failure chronic are able to experience a psychological disorder behavior in the form of rejection, angry, a feeling of fear, anxiety, the sense of helpless, depression, desperate even suicide.Psychological problems experienced by kidney failure patients chronicle demonstrated for the first time since the patient man was sentenced to experience kidney failure [4].

Incidence kidney failure chronicle at rsudinBanjarmasin from year to year always experience the significant increase. In 2013 as many as 1.921 scene, in 2014 as many as 2.025 of events and in 2015 until August recorded 2.461 of events and it would continueto increase until December of 2015 [5].

Apreliminary study of 10 male patients with kidney failure chronicle with the age range 40-65 years do hemodialysis in unit hemodialysisrsudinBanjarmasin on 11 December 2015 known that 10 people experience weight loss a significant ( about 10-25 kg), and 10 people the patient said depression and loss of appetite.They said if washing the blood they been doing so far is very disturbing, inflict pain and uncomfortable .6 of them shows the impact of allergic that is 
true of the skin like the occurrence of black skin on the surface of the skin and the threemen say if their skin pinch or grasped too hard, it will turn blue instantly. Than 10 patients kidney chronicle known 3 people 30 $\%$ gain support, a nice family and 7 people (70 $\%$ ) did not get support.There are patients who get full support every day and go to school by the awaited when undergoing hemodialysis to the finish.But there is also apatient who is every undergo hemodialysis only alone without accompanied by afamily by reason bustle and only put trust in health insurance cards (BPJS).

The research aims to understand the influence of family encouragement to anxiety on the patient with kidney failure chronicle who underwent hemodialysis in unit hemodialysis RSUD ULIN Banjarmasin.

\section{RESEARCH METHOD}

This study using analytic design survey by approach cross-sectional.The population was all the cases of kidney failure patients who underwent chronicle hemodialysis in October to December the year of 2015 will 308 people in unit hemodialysisused ironwood Banjarmasin.Samples to this research is a number of respondents who underwent hemodialysis as many as 75 people in April to may 2016 with techniques purposive sampling.

\section{RESULT}

Based on research conducted in may until April 2016 with the number of respondents as many as 75 people about the influence of family support against anxiety in patients kidney failure chronicle who undergo hemodialysis in unit hemodialysisRSUD UlinBanjarmasin, obtained the results of a general overview of the object of research that is presented in the following tables:

1. Respondents karakterisitik

a. Age of Respondent

Characteristics of age to respondents obtained based on the results of research are presented in table 4.5 under this:

Table1.Frequency distribution age of respondents

\begin{tabular}{ccc}
\hline Age (Years) & F & $\%$ \\
\hline$<25$ year & 5 & 6,66 \\
$25-50$ year & 28 & 37,33 \\
$51-75$ year & 42 & 56 \\
\hline Total & 75 & 100 \\
\hline
\end{tabular}

Table 1 is indicated that respondents the age of 51-75 years have the largest number that is 42 people ( $56 \%$ ), while thethe-the age of 25 to 50 years amounted to 28 people ( $37,33 \%$ ) and the days of \& it; 25 years of were five people ( 6,6\%).

b. Gender of Respondent

Gender respondents as for the characteristics of age to respondents 
obtained based on the results of research are presented in table 4.6 under this:

Table 2 frequency distribution Gender:

\begin{tabular}{ccc}
\hline Gender & F & $\%$ \\
\hline Male & 42 & 56 \\
Female & 33 & 44 \\
\hline Total & 75 & 100 \\
\hline
\end{tabular}

Table 2 showed that respondents to the sex men have the largest number that is 42 people ( $56 \%$ ), while the women were 33 people ( $44 \%)$.

2. Univariate Analysis

Based on the research was conducted in themarch to April 2016 with the number of respondents about 75 people about the families to support anxiety in patientskidney failure chronicle undergo hemodialysis in theunit is hemodialysis hospital Banjarmasin, obtained theresult in the abstract object research are presented in thetable-table following:

\section{a. Family Support}

Table 3.Frequency distribution support the family

\begin{tabular}{ccc}
\hline Support family & F & $\%$ \\
\hline Support & 35 & 46,7 \\
Not Support & 40 & 53,3 \\
\hline Total & 75 & 100 \\
\hline
\end{tabular}

Respondents were not gotten support of the family was 40 people (
$53,3 \%)$, while 35 people $(46,7 \%)$ providing support for patients who underwent hemodialysis in unit is hemodialysis RSUD Ulin hospital Banjarmasin

b. Anxiety

Table 4. Frequency distribution anxiety

\begin{tabular}{ccc}
\hline Anxiety & $\mathrm{f}$ & $\%$ \\
\hline Not anxiety & 34 & 45,3 \\
Anxiety weight & 41 & 54,7 \\
\hline Total & 75 & 100 \\
\hline
\end{tabular}

Respondents many having anxiety heavy namely were 41 people ( $54,7 \%$ and 34 people ( $45,3 \%$ ) not anxious.

3. Bivariate Analysis

Table5The influence of families support to anxiety

\begin{tabular}{|c|c|c|c|c|c|c|}
\hline \multirow{2}{*}{$\begin{array}{l}\text { Family } \\
\text { support }\end{array}$} & \multicolumn{4}{|c|}{$\begin{array}{c}\text { level of anxiety patients } \\
\text { hemodialisa chronicle of kidney } \\
\text { failure }\end{array}$} & \multirow[t]{2}{*}{$\mathrm{f}$} & \multirow[t]{2}{*}{$\%$} \\
\hline & $\begin{array}{c}\text { Not } \\
\text { anxiety }\end{array}$ & $\%$ & $\begin{array}{c}\text { Weigh } \\
\mathrm{t}\end{array}$ & $\%$ & & \\
\hline Negatif & 0 & 0 & 40 & 100 & 40 & 100 \\
\hline Positif & 34 & $\begin{array}{c}97, \\
1\end{array}$ & 1 & 2,9 & 35 & 100 \\
\hline Total & 34 & 44 & 41 & $\begin{array}{c}54 \\
7\end{array}$ & 75 & 100 \\
\hline \multicolumn{7}{|c|}{$\mathrm{p}=0,000<\alpha=0,05$} \\
\hline
\end{tabular}

The results of the study than 75 respondents known that respondents which have support family to the level of anxiety not sought for against 
hemodialysis function were 34 people $(97,1 \%)$, while the which has supported the negative of the family, and so experienced anxiety heavy to hemodialysis function were 40 people $(100 \%)$.

The results of the analysis by test chi-square the results that the value $\mathrm{p}=0,000<\alpha=0,05$ or it can be said that there is the influence of family encouragement to anxiety on the patient with kidney failure chronicle who underwent hemodialysis in unit hemodialysisrsudinBanjarmasin.

\section{DISCUSSION}

Based on the research done was done with 75 patients kidney failure chronicle who underwent hemodialysis in unit hemodialysisrsud ironwood Banjarmasin, be seen that the families of respondents do not support were 40 people $(53,3 \%)$,other 35 people $(46,7 \%)$ providing support for patients who underwent hemodialysis in unit hemodialysis RSUD in Banjarmasin.

The results of the questionnaire indicates that the average of respondents said agreed on statement family always notice abstinence food for you(question No. 8) And family always make the latest information about disease you (question No. 13)" and the average of respondents said do not agree upon statement family willing to get you every time will undergo hemodialysis(question No.10) and family willing to pick you up every time finished undergo hemodialysis(question No. 11)".

According to Friedman in 2008, the tasks and functions of health of families were, know health problems that experienced family, make a decision the act of about the problems faced by, do maintenance at family members sick, create and sustain / the atmosphere of an environment, so that support health every family members and maintain ties ( that ) facility that there are [6].According to Ratna for 2010 support of the family is an important factor someone else when faced the problem of a ( health and as a strategy preventive to reduce stress and view of life [7] . According to Sundari( 2011), thesupport provided the family play an important role in the success of treatment family members who are ill.The success of nurses care for a family member who sicks in hospital there will be no it means if they were not passed on at home, which then will result in clients suffered a recurrence of back 8 .Active role of family into treating a patient had an influence on the level of healing respondents, accompanying as a patient in every treatment or to maintain its role as 
well as informingbelief, the attitudes and behavior patients against his illness .

In line with research weti( 2011 ), that there is influence between family involvement with compliance patients in the treatment of hemodialysis.Family involvement can be defined as a form of social relationships that is helped by involving aspects attention, assistance and judgment of the family [9]. The family can also a factor that influences in determining treatment program in people with degrees which a person isolated from assistance others, social isolation in a negative relating to compliance treatment

From the research can be affirmed that many respondents who have heavy anxiety that is a total of 41 people ( 54.7 $\%$ ), 34 people ( $45,3 \%$ ) not anxious. This is in accordance with the opinions Sundari( 2011 ) that anxiety is a problem common psychological 8, but in fact which happens on the ground, then 30 respondents ( $100 \%)$ the proportion of the number of respondents who had mild anxiety to be the highest

This can be attributed that the majority of respondents has long undergonehemodialysis and indirectly has experienced phase adaptation and also received the insurer of some to financing therapy.In accordance with statements from Ballard (Smeltzer\& bare) 2011. that not only stressor due to health problems just experienced a person suffering from chronic health problems, but changes in the role in the life of and needs money because of diseases experienced will increase stressor.In addition,Smeltzer\& amp; bare ( 2011 ) revealed that a person with certain stressor will experience phase example of an adaptation which each individual has the ability to overcome the problem of or respond with a different [3].

Anxiety significantly improved a whole burden disease in patients with a medical condition of chronic.Anxiety also associated with increased morbidity disease $[7,10]$.This condition also helps guide patients his family to available resources to get assistance and support.On this situation, patients need linked to a person or family as a share in times of stress and lose vigor[3,10].

On condition that forcing someone to undergo hemodialysis routine and uncertainty and the period therapy spent is stressor powerful to trigger anxiety.Inaddition, a patient with kidney failure chronic is also bear second thoughts about the process of the course of a disease experienced as,symptoms inflicted disease,complication disease and dialysistherapy, the eat and drink that is part of therapy, financial problems,psychology, and 
psikososial.This really needs attention and if health workers and family face patients facing health problems chronic, for chronic disease can cause trouble psikosomatis so it takes care and comprehensive treatment and holistic.

The influence of family encouragement to anxiety on the patient with kidney failure chronicle who underwent hemodialysis in unit hemodialysisused ironwood Banjarmasin the results of the study than 75 respondents known that respondents which have support family with no anxiety to hemodialysis function were 34 people $(97,1 \%)$, while the which do not get support of the family with anxiety heavy to hemodialysis function were 40 people ( $100 \%)$ ).The results of the analysis by test chi-square the results that the value $p=0,000<\alpha=0,05$ or it can be said that there is the influence of family encouragement to anxiety on the patient with kidney failure chronicle who underwent hemodialysis in unit hemodialysisRSUD Ulin Banjarmasin.

\section{CONCLUSION}

Proper family support and in accordance with that which is required patients anxiety can improve life and give renewed energy to live a better life and focus on increasing the meaning of life.On the other hand, improper support can add on themind and are critical to patients anxiety levels, for that family and health service providers are expected to provide motivation and support to patients who underwent dialysis able to control chronicstressor experienced that would improve the quality of life of patients with chronic health problems.

\section{REFERENCE}

[1] Kemenkes RI. Infodantin: Gagal Ginjal Kronik. Jakarta: Direktorat Kementrian Kesehatan RI. 2015.

[2] Ghamari, M. Family Function and depression. anxiety, anda somatization among collage students International Journal of Academic Research in Business and Social Sciencews, 2 (5),pp.101-105. 2012.

[3] Wang, J. K., \& Zhao. X.D. Research on Social support and family function for depressed family member. Journal of Clinical Psychiatry, 21, 149-151 (in Chines). 2011.

[4] Barrera, T. L. \& Norton, P.J. Quality of life impairment in generalized anxiety disordes, social phobia, and panic disorders. 23, 1086-1090. 2010.

[5] Weti, A.N. Hubungan Dukungan Keluarga dengan Derajat Kecemasan pada Pasien Gagal Ginjal dalam Menjalani Proses Hemodialisis di RSUD Paku Alam. Jurnal Kesehatan: Edisi 2 Hal 14-16. [Internet] tersedia di http//:www.healthy.co.id. [diakses: 8 Februari 2016]. 2011.

[6] YDGI. Penyakit Ginjal Kronik, Epidemi Global Baru. Diakses pada 15 Maret 2012.

[7] Miller, I, W, Ryan. C.E., Keitner, G.I. Bishop, D.S \& Epstein. N.B. The Mc Master approach to families. Theory assessment. treatment anda research, 
Journal of Family Therapy, 22, 168-189. 2000.

[8] Sundari. Hubungan Dukungan Keluarga dengan Derajat Kecemasan pada Pasien Gagal Ginjal dalam Menjalani Proses Hemodialisis di Klinik Pengobatan Yulius. Jurnal Kesehatan: Edisi 5 Hal 912. [Internet] tersedia di http//:www.healthy.co.id. [diakses: 8 Februari 2016]. 2011.

[9] Bear, C Weisberg, R. B., \& Keller, M. B. Health related quality of life across the anxiety disordes. Findings from a sample of primary care patients. Journal of Anxiety Disorder, 24, pp. 559-564. 2010.

[10] Ratna. W. Hubungan Dukungan Keluarga dengan Kecemasan Pasien Gagal Ginjal dalam Menjalani Proses Hemodialisis di Balai Pengobatan Ukhuwah Malang. Jurnal Kesehatan: Edisi 6 Hal 11-14. Universitas Airlangga [Internet] tersedia di http//:www.healthy.co.id. [diakses: 8 Februari 2016]. 2010. 